\title{
Environmental Contaminants in Nestling Bald Eagles Produced in Montana and Wyoming
}

Author(s): Jason T. Carlson, Alan R. Harmata, and Marco Restani

Source: Journal of Raptor Research, 46(3):274-282.

Published By: The Raptor Research Foundation

https://doi.org/10.3356/JRR-11-68.1

URL: http://www.bioone.org/doi/full/10.3356/JRR-11-68.1

BioOne (www.bioone.org) is a nonprofit, online aggregation of core research in the biological, ecological, and environmental sciences. BioOne provides a sustainable online platform for over 170 journals and books published by nonprofit societies, associations, museums, institutions, and presses.

Your use of this PDF, the BioOne Web site, and all posted and associated content indicates your acceptance of BioOne's Terms of Use, available at www.bioone.org/ page/terms_of use.

Usage of BioOne content is strictly limited to personal, educational, and noncommercial use. Commercial inquiries or rights and permissions requests should be directed to the individual publisher as copyright holder. 


\title{
ENVIRONMENTAL CONTAMINANTS IN NESTLING BALD EAGLES PRODUCED IN MONTANA AND WYOMING
}

\author{
JASON T. CARLSON ${ }^{1}$ \\ Department of Biological Sciences, St. Cloud State University, St. Cloud, MN 56301 U.S.A. \\ Alan R. HARMATA \\ Ecology Department, Montana State University, Bozeman, MT 59717 U.S.A. \\ MARCO RESTANI ${ }^{2}$ \\ Department of Biological Sciences, St. Cloud State University, St. Cloud, MN 56301 U.S.A.
}

\begin{abstract}
Upper-trophic level piscivores, such as Bald Eagles (Haliaeetus leucocephalus), may be at risk of exposure to environmental contaminants in the western United States from coal-fired power plants and coal-bed methane wells. We collected 64 blood samples from nestling Bald Eagles in southeastern Montana and northwestern Wyoming during 2007-08 for analyses of heavy metals, trace elements, and organochlorine compounds. Mercury was detected in all blood samples and averaged $( \pm \mathrm{SD}) 0.28 \pm 0.20 \mathrm{ppm}$. Most nestlings $(82.8 \%)$ had concentrations near expected background levels, but $7.8 \%$ had elevated $(>0.7 \mathrm{ppm})$ mercury levels. Nestlings in Wyoming $(\bar{x}=0.37 \pm 0.22 \mathrm{ppm})$ had higher blood mercury concentrations than nestlings from Montana $\left(\bar{x}=0.22 \pm 0.17 \mathrm{ppm} ; t_{31}=3.151, P=0.015\right)$. In Montana, nestlings sampled on Yellowstone River tributaries had lower blood mercury concentrations $(\bar{x}=0.12 \pm 0.10 \mathrm{ppm})$ than nestlings from the main stem of the Yellowstone River $(\bar{x}=0.28 \pm 0.21 \mathrm{ppm})$ and Wyoming $(\bar{x}=0.37 \pm$ $\left.0.22 \mathrm{ppm} ; F_{2,32}=12.439, P<0.001\right)$. Blood levels of mercury and selenium were positively correlated $\left(r_{S}=\right.$ $0.281, n=64, P=0.024)$. Lead $(\bar{x}=0.07 \pm 0.08 \mathrm{ppm})$ was detected in $81.3 \%$ of nestlings, but only $11.5 \%$ of those were considered above background levels. The organochlorine p,p'-DDE $(\bar{x}=0.003 \pm 0.003 \mathrm{ppm})$ was detected in $69.6 \%$ of nestlings sampled. Compared to previous studies in the region, mercury contamination has become more widespread, whereas the prevalence of lead contamination was similar to that of the past. Based on this study, we suggest that some Bald Eagle nestlings may be experiencing adverse effects from mercury contamination, and recommend that additional monitoring take place as coal-fired power plants and the coal-bed methane industry continue to expand.
\end{abstract}

KeY Words: Bald Eagle, Haliaeetus leucocephalus; coal-bed methane, lead; mercury; Montana; Wyoming.

\section{CONTAMINANTES AMBIENTALES EN POLLUELOS DE HALIAEETUS LEUCOCEPHALUS PRODUCI- DOS EN MONTANA Y WYOMING}

Resumen.-Las especies piscívoras de un nivel trófico alto, como Haliaeetus leucocephalus, pueden estar en riesgo de exposición a contaminantes ambientales provenientes de plantas de generación eléctrica a carbón y pozos de metano de mantos carboníferos en el oeste de los Estados Unidos. Colectamos 64 muestras de sangre de pichones de H. leucocephalus en el sudeste de Montana y noroeste de Wyoming durante el 2007 y 2008 para análisis de metales pesados, oligoelementos y compuestos organoclorados. Se detectó mercurio en todas las muestras de sangre, el cual promedió ( \pm DE) $0.28 \pm 0.20 \mathrm{ppm}$. La mayoría de los pichones $(82.8 \%)$ presentó concentraciones cercanas a los niveles de fondo esperados, pero $7.8 \%$ tuvo niveles elevados $(>0.7 \mathrm{ppm})$ de mercurio. Los pichones de Wyoming $(\bar{x}=0.37 \pm 0.22 \mathrm{ppm})$ presentaron concentraciones de mercurio en sangre mayores que las de los pichones de Montana $\left(\bar{x}=0.22 \pm 0.17 \mathrm{ppm} ; t_{31}=3.151, P=\right.$ 0.015). En Montana, los pichones muestreados en tributarios del Río Yellowstone presentaron concentraciones de mercurio en sangre menores $(\bar{x}=0.12 \pm 0.10 \mathrm{ppm})$ que las de los pichones del cauce principal del Río Yellowstone $(\bar{x}=0.28 \pm 0.21 \mathrm{ppm})$ y Wyoming $\left(\bar{x}=0.37 \pm 0.22 \mathrm{ppm} ; F_{2,32}=12.439, P<0.001\right)$. Los niveles en sangre de mercurio y selenio estuvieron positivamente correlacionados $\left(r_{S}=0.281, n=64, P=\right.$

\footnotetext{
${ }^{1}$ Present address: St. Cloud Technical and Community College, 1500 Northway Drive, St. Cloud, MN 56303 U.S.A.

2 Email address: restani@stcloudstate.edu
} 
0.024). Se detectó plomo $(\bar{x}=0.07 \pm 0.08 \mathrm{ppm})$ en $81.3 \%$ de los pichones, pero sólo $11.5 \%$ de ellos fueron considerados como por encima de los niveles de fondo. El compuesto organoclorado p,p'-DDE $(\bar{x}=0.003 \pm$ $0.003 \mathrm{ppm}$ ) fue detectado en $69.6 \%$ de los pichones muestreados. Comparado con estudios previos en la región, la contaminación por mercurio se ha extendido, mientras que la prevalencia de contaminación por plomo fue similar a la del pasado. Basados en este estudio, sugerimos que algunos polluelos de H. leucocephalus pueden estar experimentando efectos adversos por contaminación con mercurio y recomendamos que se establezcan monitoreos adicionales mientras las plantas de generación eléctrica a carbón y la industria de pozos de metano de mantos carboníferos continúen su expansión.

[Traducción del equipo editorial]

In an evaluation of 38 bird species, Evers et al. (2005), reported that piscivores have the highest contaminant levels, and that Bald Eagles (Haliaeetus leucocephalus) were the species most at risk in aquatic ecosystems. Although point-source releases of mercury have been greatly reduced during the past two decades (Heinz 1996), concentrations in some Bald Eagle populations have not decreased. For example, mercury in nestling Bald Eagles from Michigan did not decrease between 1989 and 1999 (Bowerman et al. 2002). In Maine, mercury concentrations in Bald Eagle eggs have not decreased since 1970, and nestling mercury levels in blood have not declined since 1991 (DeSorbo and Evers 2005). Weech et al. (2003) recently reported the first known death of a Bald Eagle caused by mercury poisoning.

Coal-fired power plants have contributed $40 \%$ of anthropogenic mercury emissions to the atmosphere (U.S. Environmental Protection Agency 1997), and their emissions were once estimated to be two times higher than natural emissions from volcanoes, vents, and hot springs (Nriagu 1989). Subsequent atmospheric deposition and effluent sources in aquatic systems have raised mercury levels 2-4 times above natural levels (National Research Council 1978). Mercury deposition in Montana is above detectable levels only near coal-fired power plants (U.S. Environmental Protection Agency 1997), where most deposition occurs within 80$800 \mathrm{~km}$ from the plant (Cohen et al. 2004).

Another potential significant source of environmental contaminants for eagles in Montana is associated with coal-bed methane production, a recently developed industry on which little environmental research has been conducted (Stearns et al. 2005). Wastewater produced from methane wells is discharged or may seep from holding ponds into surface water (Nuccio 2000, Regele and Stark 2000). This water may contain bromine, barium, magnesium, ammonia, arsenic, cobalt, chromium, copper, manganese, nickel, and mercury, most of which can be harmful to wildlife (Rice et al. 2000). Although some of the contaminants are at very low levels in wastewater, the volume of discharge is increasing significantly. Wastewater production from coal-bed methane production rose from 130000 barrels/day to 1.28 million barrels/day from 1997 to 2000 . Moreover, the number of coal-bed methane wells is predicted to increase 6-28 times within the next 20-30 yr (Rice et al. 2000); thus, negative effects of contaminated water on aquatic habitats and wildlife may be pronounced (Stearns et al. 2005). The Powder River Basin of southern Montana and northern Wyoming is the center of coal-bed methane production within the United States.

Both the Montana Bald Eagle Management Plan (Montana Bald Eagle Working Group 1994) and the Greater Yellowstone Bald Eagle Management Plan (Greater Yellowstone Bald Eagle Working Group 1996) suggest sampling of environmental contaminants in eagles every $3 \mathrm{yr}$ and $5 \mathrm{yr}$, respectively. With the exception of Harmata (2011), no contaminants sampling has been conducted in $11 \mathrm{yr}$ in Montana or Wyoming. The National Bald Eagle Management Guidelines call for monitoring populations where bioaccumulating compounds have been documented as part of delisting activities (U.S. Fish and Wildlife Service 2006). In this study, we measured contaminant levels in nestling Bald Eagles from Montana and Wyoming to fulfill these management recommendations and to address concerns over recent eagle deaths from mercury contamination (Harmata 2011). Our objectives were to measure the prevalence and concentrations of environmental contaminants in nestling Bald Eagles produced in Montana and Wyoming to answer the following questions: (1) is mercury contamination in eaglets at a level of concern and are there geographic patterns of mercury contamination?; (2) is there a relationship between mercury and selenium in nestling tissues, given that selenium is known to mitigate the effects of mercury toxicity through sequestration in certain tissues?; (3) how do current contaminant levels compare to previous concentrations?; 
(4) Are contaminants from coal-bed methane wastewater at a level of concern in nestling eagles? We also examined levels of organochlorine (OC) compound levels (e.g., DDE), because they may persist in local environments from past pesticide use. We compare our mercury results with those found in three previous studies in the region (Harmata and Oakleaf 1992, Harmata and Restani 1995, Harmata 2011).

\section{METHODS}

Our study area in Montana covered a narrow strip of northern floodplain deciduous forest from Livingston, Montana east toward the North Dakota border along the Yellowstone River and its major tributaries, the Bighorn, Tongue, and Powder rivers. Lower reaches of the rivers contained warmer water, gentler gradients, lower oxygen concentration, higher turbidity, greater sediment deposition, and finer substrate than upper reaches (Zelt et al. 1999). Fish species present in the middle and lower reaches of the Yellowstone and its tributaries included goldeye (Hiodon alosoides), burbot (Lota lota), sauger (Sander canadensis), walleye (Sander vitreus), channel catfish (Ictalurus punctatus), sunfishes (Centrarchidae spp.), drum (Aplodinotus grunniens), rainbow trout (Oncorhynchus mykiss), and brown trout (Salmo trutta; Zelt et al. 1999, Galat et al. 2005). Summers were sunny and warm and winters were cold with moderate snowfall. Mean monthly temperatures ranged from $-11^{\circ} \mathrm{C}$ in January to $22^{\circ} \mathrm{C}$ in July. Precipitation was low, with $80 \%$ of the annual 30-36 cm falling in April-September (Compton et al. 1988). Major population centers located on the Yellowstone River and tributaries included Billings, Laurel, Livingston, Hardin, Miles City, Broadus, Glendive, and Sidney, Montana (Zelt et al. 1999). Agriculture was the most common land use in the riparian and adjacent areas, and most untilled areas were grazed extensively by cattle (Dusek et al. 1989, Zelt et al. 1999). Oil and gas production and coal mining were prevalent in the Bighorn and Powder River basins. Many tributaries were dewatered and irrigation accounted for $90 \%$ of water use.

In Wyoming, we analyzed blood from Bald Eagle nestlings along the upper Snake River, Jackson Lake, and Lower Slide Lake from the Jackson Lake dam to Hoback Junction. Headwaters of the river were fed from the south-central Rockies terrestrial ecoregion, an area of mountain ranges, intermontane valleys, and alpine lakes. Local fish species included Yellowstone cutthroat trout (O. clarki bouvieri), Snake River finespotted cutthroat trout (O. clarki behnkei), bull trout (Salvelinus confluentus), brown trout, brook trout (S. fontinalis), lake trout (S. namaycush), smallmouth bass (Micropterus dolomieui), carp (Cyprinus carpio), largemouth bass (M. salmoides), channel catfish, and whitefish (Coregonus clupeaformis; Stanford et al. 2005). During snowmelt, water clarity was low, but relatively high at other times. Climate was continental with cool summers and cold winters. Mean January temperature was $-11.4^{\circ} \mathrm{C}$, mean July temperature was $14.5^{\circ} \mathrm{C}$, and average annual precipitation was $568 \mathrm{~mm}$ in the region (Swenson et al. 1986). No major human population centers or point sources of pollution existed along the upper Snake River. However, the river was impacted by isolated mines, cattle grazing, irrigation, and many dams and water diversions.

We chose Bald Eagle nests for contaminant sampling based on nest activity, landowner permission, and suitability/safety of the nest tree for climbing. We sampled nests in different territories in 2007 and 2008. We climbed to nests by rope-assisted climbing in late May and early June, when nestlings were 4-10 wk of age (Bortolotti 1984). We used a 22gauge sterile syringe to collect 1-3 cc of blood from the brachial vein of each nestling. Blood was placed in a CaEDTA preservative vacutainer for heavy metal and trace element analysis. From the largest nestling, we also collected an additional 2-3 cc of blood for organochlorine pesticide analysis (both in 2007 and 2008 in Montana, only in 2007 in Wyoming). This sample was centrifuged and the serum separated for analysis. We refrigerated and stored samples until shipment to laboratories at the end of each field season in June. Total processing time averaged $10 \mathrm{~min}$ per nestling and $90 \mathrm{~min}$ at nests.

Blood samples were shipped to Michigan State University, College of Veterinary Medicine, Diagnostic Center for Population and Animal Health (DCPAH), Toxicology Section, for analysis. Whole blood was analyzed for the following heavy metals and trace elements (detection limit): arsenic, cadmium, mercury, and selenium (1 part per billion [ppb]); antimony, lead, and thallium (5 ppb); and chromium (25 ppb). Blood was analyzed for total mercury by cold vapor atomic absorption (Wood et al. 1996) using an M-6000 Analyzer (CETAC Technologies); for lead, chromium, arsenic, cadmium, thallium and antimony by inductively coupled plasma (ICP) atomic emission spectrometry (Vista Axial ICP-AES; modified from Braselton et al. 1981 and Stowe et al. 1985); and for selenium by ICP-mass 
Table 1. Whole blood concentrations (ppm wet weight) of mercury ( $\mathrm{Hg})$, selenium (Se), lead ( $\mathrm{Pb}$ ), and chromium (Cr) in nestling Bald Eagles sampled in Montana and Wyoming, U.S.A., 2007 and 2008.

\begin{tabular}{lccccc}
\hline & & \multicolumn{4}{c}{ MEAN \pm SD (RANGE) } \\
\cline { 3 - 6 } Location & $n$ & $\mathrm{Hg}$ & $\mathrm{Se}$ & $\mathrm{Pb}$ & $\mathrm{Cr}$ \\
\hline Montana & 39 & $0.22 \pm 0.17$ & $0.99 \pm 0.40$ & $0.09 \pm 0.09$ & $0.01 \pm 0.00$ \\
& & $(0.10-0.85)$ & $(0.49-2.23)$ & $(0.01-0.31)$ & $(0.01-0.02)$ \\
Wyoming & 25 & $0.37 \pm 0.22$ & $1.58 \pm 0.70$ & $0.05 \pm 0.05$ & $0.02 \pm 0.01$ \\
& & $(0.11-0.80)$ & $(0.55-3.36)$ & $(0.01-0.19)$ & $(0.01-0.04)$ \\
Total & 64 & $0.28 \pm 0.20$ & $1.22 \pm 0.61$ & $0.07 \pm 0.08$ & $0.01 \pm 0.01$ \\
& & $(0.10-0.85)$ & $(0.49-3.36)$ & $(0.01-0.31)$ & $(0.01-0.04)$ \\
\hline
\end{tabular}

spectrometry (Agilent 7500ce ICP-MS; Wilbur 2007). The AA analyzer was calibrated using 0, 25, 100, 500, and 5000 ppt standard solutions, ICP-AES was calibrated with 0,1 and 10 ppm standards, ICP-MS was calibrated with $0,5,50,250$ and 500 ppb standards, and final concentrations were measured against standard reference solutions and digest blanks arranged for a linear relationship. Quality control was maintained by monitoring of results obtained with Bio-Rad (Hercules, California, U.S.A.) Lypochek Whole Blood Metals Controls 1 and 2. Calibrations were also checked against nitric acid digested Standard Reference Materials, such as NIST SRM 2976 mussel (see Harmata 2011 for detailed laboratory methodology).

Blood was also analyzed at DCPAH for the following organochlorine pesticides (as described in Hollamby et al. 2004; detection limit of 1 ppb): aldrin, alpha_BHC, beta_BHC, dieldrin, heptachlor, heptachlor epoxide, methoxychlor, oxychlordane, P, $\mathrm{P}^{\prime}$ DDE, P,P'-DDD, P,P'-DDT, and theta_BHC. Contaminants were analyzed in serum samples using a Varian 3400 Gas Chromatograph. Concentrations were determined in comparison to spiked serum samples containing 1 ppm of polychlorinated biphenyl, and 0.5 ppm of chlorinated pesticide mix. Extractions were performed with hexane/acetone, 9:1, and final dried extracts were re-suspended in ethanol/iso-octane, 2:8 (Hollamby et al. 2004). Blank solvent injections were run through the analyzer between samples. Extraction efficiency was based on recovery of compound standards from spiked blanks to ensure all recoveries exceeded $60 \%$. Blanks, spikes, standards, and specimens were run simultaneously and GC peak identities were verified if retention times varied by $<0.1 \mathrm{~min}$ from standards (see Harmata 2011 for detailed laboratory methodology).
Contaminant concentrations were reported in parts per million wet weight from DCPAH. Because of relatively small samples sizes, we combined the 2007 and 2008 data. We separated nestlings by state, and further separated nestlings from Montana into groups based on water body adjacent to nests (i.e., Yellowstone River, Snake River, Yellowstone River tributaries). We log-transformed data to improve normality and used an independent samples $t$-test or one-way ANOVA to compare arithmetic means. When statistical significance was analyzed among groups, we averaged contaminant concentrations of nestlings within nests and only performed tests when $\geq 50 \%$ of individual samples had detectable contaminants. We assigned a value of one-half the detection limit of the test to samples below the detection limit for the respective contaminant (Wiemeyer et al. 1989). Spearman's rank correlation was used to test for relationships between blood concentrations of mercury and selenium. We completed statistical analyses using SPSS 14.0 (SPSS 2006) and assigned significance at $P \leq 0.05$.

\section{Results}

We sampled 41 nestlings from 18 nests $(\bar{x}=2.28$ \pm 0.75 nestlings/nest, $\bar{x}=46 \pm 11 \mathrm{~d}$ old) in Montana and 25 nestlings from 15 nests in Wyoming $(\bar{x}$ $=1.67 \pm 0.72$ nestlings $/$ nest, $\bar{x}=54 \pm 8.1 \mathrm{~d}$ old; blood samples were obtained from 39 of 41 Montana nestlings). Heavy metals detected in $\geq 50 \%$ of nestling blood samples included mercury (100\%), selenium $(100 \%)$, lead $(79.7 \%)$, and chromium (56.3\%; Table 1). Other elements detected in $<50 \%$ of whole blood samples included antimony, cadmium, arsenic, and nickel (Table 2).

Wyoming nestlings had higher mercury levels in blood $\left(t_{31}=3.151, P=0.004\right)$ than Montana nestlings (Fig. 1). When grouped by water body (Yellowstone 
Table 2. Frequency of occurrence, mean $\pm \mathrm{SD}$, and range (ppm whole blood) of cadmium (Cd), antimony (Sb), nickel (Ni), and arsenic (As) in blood of nestling Bald Eagles sampled in Montana and Wyoming, U.S.A., 2007 and 2008. Cd, Sb, $\mathrm{Ni}$, and As were detected in $\leq 50 \%$ of samples.

\begin{tabular}{lccccc}
\hline & & \multicolumn{4}{c}{ Number Detected MEAN \pm SD (RANGE) } \\
\cline { 3 - 5 } Location & $n$ & $\mathrm{Cd}$ & $\mathrm{Sb}$ & $\mathrm{Ni}$ & $\mathrm{As}$ \\
\hline Montana & 39 & 4 & 2 & 10 & $\mathrm{nd}^{\mathrm{a}}$ \\
& & $0.023 \pm 0.023$ & $0.006 \pm 0.0$ & $0.044 \pm 0.056$ & $(0.005-0.146)$ \\
Wyoming & 25 & $(0.001-0.044)$ & $(0.006)$ & 15 & 6 \\
& & 16 & $0.008 \pm 0.001$ & $0.046 \pm 0.044$ & $0.027 \pm 0.017$ \\
Total & & $(0.004-0.038)$ & $(0.007-0.009)$ & $(0.006-0.142)$ & $(0.006-0.049)$ \\
& 64 & 20 & 4 & 25 & 6 \\
& & $0.013 \pm 0.011$ & $0.008 \pm 0.001$ & $0.037 \pm 0.040$ & $0.027 \pm 0.017$ \\
& & $(0.001-0.044)$ & $(0.006-0.009)$ & $(0.005-0.146)$ & $(0.006-0.049)$ \\
\hline
\end{tabular}

River, Snake River, or Yellowstone River tributaries combined), nestlings from Yellowstone River tributaries had lower blood mercury levels $(\bar{x}=0.12 \pm$ $0.10 \mathrm{ppm}, n=8)$ than Yellowstone River nestlings $(\bar{x}=0.28 \pm 0.21 \mathrm{ppm}, n=10)$ and Snake River nestlings $\left(\bar{x}=0.37 \pm 0.22 \mathrm{ppm}, n=15 ; F_{2,32}=\right.$ $12.439, P<0.001)$. Wyoming nestlings also had higher blood selenium levels than Montana nestlings $\left(t_{25}\right.$ $=3.574, P<0.001$; Fig. 1). Whole blood mercury and selenium were positively correlated $\left(r_{S}=0.281, n=\right.$ 64, $P=0.024)$.

Blood samples from 23 nestling Bald Eagles were analyzed for organochlorine compounds. Only p,p'DDE was found above detectable levels and no differences existed between Montana $(\bar{x}=0.004 \pm$ 0.004 ppm, detected in 9 of 11 nestlings) and Wyo$\operatorname{ming}(\bar{x}=0.002 \pm 0.002 \mathrm{ppm}$, detected in 7 of 12 nestlings); however, the sample size was small.

\section{DISCUSSION}

All nestlings sampled contained detectable levels of mercury in blood. Mean blood mercury levels $(\bar{x}=0.28 \mathrm{ppm})$ were similar to the level $(\bar{x}=$ $0.23 \mathrm{ppm}$ ) from nestlings sampled in Montana between 1985 and 1991 (Harmata and Oakleaf 1992). However, mercury was detected in only $50 \%$ of those samples; thus, the prevalence of mercury contamination has become more widespread during the last decade (see Harmata 2011, who used similar methodology as in our study). Mercury levels in our study also corresponded to background mercury levels found in captured Bald Eagles in the northwestern U.S. $(\bar{x}=0.23$ ppm, range $0.17-0.31$ ppm; Wiemeyer et al. 1989).
Mercury concentrations in blood in this study fell within the range of levels detected in other populations. Lower levels have been documented in South Carolina $(\bar{x}=0.10 \mathrm{ppm}$, range $0.03-0.25 \mathrm{ppm}$; Jagoe et al. 2002), Florida ( $\bar{x}=0.16 \mathrm{ppm}$, range 0.02-0.61 ppm; Wood et al. 1996), and the state of Washington $(\bar{x}=0.23$ ppm, range $0.075-0.65$ ppm; Wiemeyer et al. 1989). Higher blood mercury levels were found in Maine $(\bar{x}=0.53$, range $0.1-1.20 \mathrm{ppm}$; DeSorbo and Evers 2005), the Columbia River Estuary $(\bar{x}=0.47$ ppm, range $0.19-1.40$ ppm; Anthony et al. 1993), and Oregon $(\bar{x}=1.2$ ppm, range $<$ detection limit -4.20 ppm; Wiemeyer et al. 1989).

DeSorbo and Evers (2005) proposed mercury exposure categories for Bald Eagle nestlings based on relationships between mercury and reproductive success in Common Loons (Gavia immer). Mercury levels in most nestlings from Montana and Wyoming fell within the "background" (0-0.39 ppm) and "moderate" (0.4-0.69 ppm) categories. However, $7.8 \%$ of nestlings sampled contained "elevated" (0.7-0.99 ppm) mercury levels. The "elevated" level in nestling Bald Eagles corresponds to a level $>3.0$ ppm in Common Loons (DeSorbo and Evers 2005), a threshold where negative effects on reproductive success and behavior became evident (Evers et al. 2004). This cross-species comparison may be tenuous because Bald Eagles appeared to be more efficient at detoxifying mercury in brain tissue than loons (Scheuhammer et al. 2008). Nonetheless, mercury concentrations in Bald Eagles from the Great Lakes caused significant neurological changes in brain receptor and enzyme activity (Rutkiewicz et al. 2011). 

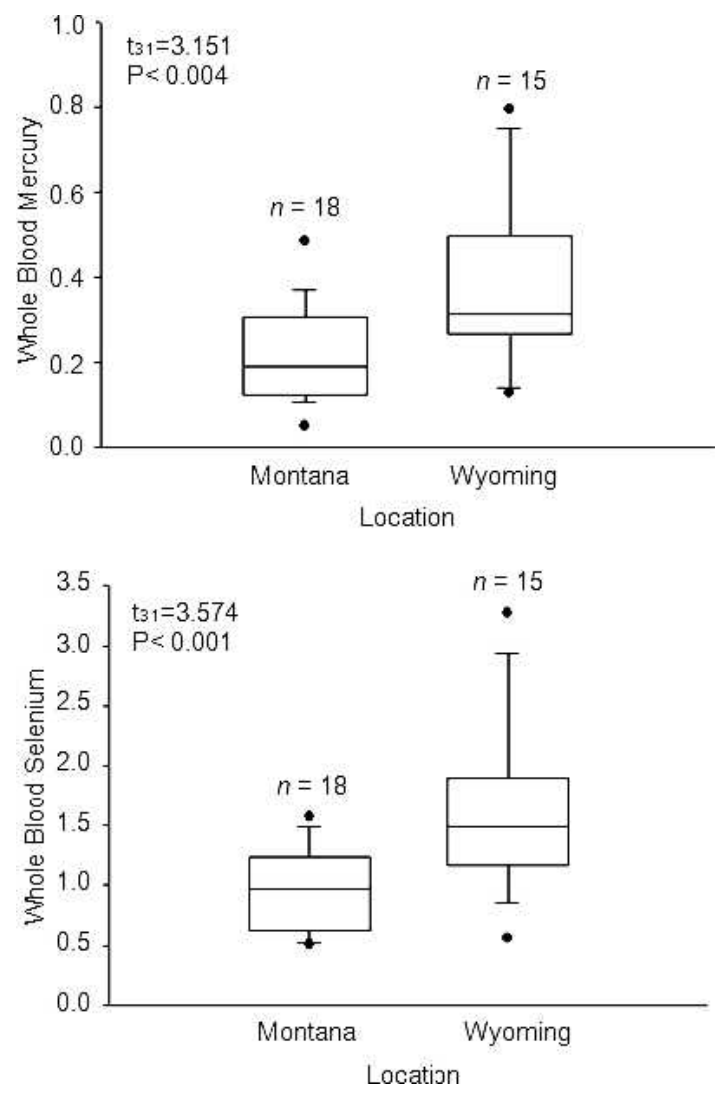

Figure 1. Nest mean whole blood (ppm wet weight) mercury and selenium concentrations in Bald Eagle nestlings sampled from Montana and Wyoming, U.S.A., 2007 and 2008. Each box displays median and interquartile range (ITQ); whiskers represent $\pm 1.5 \times \mathrm{IQR}$ and filled circles represent outliers.

Selenium mitigates the effects of mercury toxicity by sequestration as insoluble $\mathrm{HgSe}$ in liver, kidneys, and brain (Cuvin-Aralar and Furness 1991, Scheuhammer et al. 1998, Hopkins et al. 2007). In this study, selenium and mercury levels in blood were correlated, albeit poorly $\left(r_{S}=0.281\right)$. Other studies found very strong correlations between mercury and selenium in brain, liver, and kidneys (Hopkins et al. 2007, Rutkiewicz et al. 2011). At high levels of mercury concentration, selenium and mercury occur at approximately a 1:1 molar ratio (2.54 ppm Se: $1 \mathrm{ppm}$ $\mathrm{Hg}$ ) in Bald Eagle brain, liver, and kidneys, and at that level selenium is effective in detoxifying mercury (Scheuhammer et al. 2008). In our study, selenium and mercury in blood occurred at a ratio greater than 1:1. Blood is not a known sequestration tissue, which may explain the poor correlation we found.
A few geographic patterns of mercury contamination emerged from our study. A larger proportion of nestlings from Wyoming had "elevated" concentrations of mercury, and Wyoming nestlings also had higher average blood mercury compared to Montana nestlings. After we grouped nestlings by water body (Yellowstone River, Snake River, and Yellowstone River tributaries), differences in mercury levels became apparent. Nestlings sampled on Yellowstone River tributaries in Montana (Powder River, Tongue River, and Bighorn River) had lower mercury concentrations than nestlings on the main stem of the Yellowstone and Snake Rivers. Whitetailed Eagles (H. albicilla) in Sweden (Olsson et al. 2000) and Bald Eagles along the Great Lakes (Dykstra et al. 2010) also exhibited geographic differences in mercury concentrations. The adult population on our study areas in Montana and Wyoming was nonmigratory, as was that studied by Olsson et al. (2000), who concluded that blood concentrations of mercury in nestlings were as useful a biomarker of contamination as egg concentrations.

Nestling Bald Eagles in our study had detectable levels of contaminants found in coal-bed methane wastewater (e.g., mercury, lead, selenium, chromium, arsenic, and nickel). Other than mercury and lead, concentrations of these contaminants in nestling blood were below levels associated with adverse effects. However, each coal-bed methane well produces approximately $57 \mathrm{~L}$ of discharge water per minute (Regele and Stark 2000). Discharge water is projected to increase significantly (6-28 times) with further industry development in the Powder River Basin (Rice et al. 2000). Thus, Bald Eagles may become vulnerable to water quality degradation from coal-bed methane wastewater.

Although lead was detected in $81.3 \%$ of nestlings $(\bar{x}=0.07 \mathrm{ppm}), 88.5 \%$ of nestlings contained "background" levels $(<0.20 \mathrm{ppm})$ and only $11.5 \%$ were considered "exposed" ( $\geq 0.20$ to $0.59 \mathrm{ppm}$; Redig 1984). All "exposed" nestlings were sampled in Montana. Harmata and Oakleaf (1992) detected lead in $33.3 \%$ of nestlings sampled using a detection limit of $0.06 \mathrm{ppm}$, and reported a higher mean blood level $(0.14 \mathrm{ppm})$ than observed in our study. Eliminating lead levels below $0.06 \mathrm{ppm}$ in our study produced a detection rate of $37.5 \%$, comparable to that observed in the late 1980s.

Despite being banned in 1972, p,p'-DDE, a metabolite of the insecticide DDT, was detected in $69.6 \%$ of Bald Eagle nestlings, although all concentrations were well below levels considered adverse (Blus 
1996, Elliott and Harris 2001/2002). A detection rate of $67 \%$ and higher mean level $(\bar{x}=0.007 \mathrm{ppm})$ were reported a decade earlier in free-flying Bald Eagles from Montana when using a detection limit of 0.003 ppm (Harmata and Restani 1995). Eliminating values below $0.003 \mathrm{ppm}$ in our study produced a detection rate of $48 \%$. The decline in DDE concentrations mirrored that observed for Bald Eagles nesting along the Great Lakes (Dykstra et al. 2010).

In summary, some local mercury contamination in Bald Eagle nestlings was evident and contamination has become more widespread compared to the previous decades. However, the population of Bald Eagles that was sampled in our study has increased every decade since comprehensive monitoring began in 1980 (Hammond 2010). As of 2007, 151 new coalpowered plants are proposed for construction in the United States, including seven in Montana and 11 in Wyoming (U.S. Department of Energy 2007). Therefore monitoring of mercury in Bald Eagle nestlings should continue. Contaminants associated with coalbed methane wastewater were not detected at a level of concern, yet with projected industry expansion, regular sampling of Bald Eagle nestlings from the Powder River Basin should continue.

\section{ACKNOWLEDGMENTS}

L. Apple, K. DuBois, A. Puchniak, and K. Undlin provided data and technical assistance. G. Montopoli trained the senior author in tree-climbing techniques, and C. Cyrus, $\mathrm{H}$. Harlow, and T. Karshnik assisted with fieldwork. Helpful project administration came from B. Kjellberg, M. McKenzie, and J. Ensign. Financial support was provided by the U.S. Bureau of Land Management and St. Cloud State University. The U.S. Bureau of Land Management, Miles City, MT, provided housing and vehicles. We are also grateful to many private landowners for allowing access to Bald Eagle nests on their property. The comments of three anonymous reviewers and C. Dykstra improved the draft manuscript.

\section{Literature Cited}

Anthony, R.G., M.G. Garrett, And C.A. Schuler. 1993. Environmental contaminants in Bald Eagles in the Columbia River Estuary. Journal of Wildlife Management 57:10-19.

Blus, L.J., S.N. Wiemeyer, AND C.J. Henny. 1996. Organochlorine pesticides. Pages $61-70$ in A. Fairbrother, L.N. Locke, and G.N. Hoff [EDS.], Noninfectious diseases of wildlife. Iowa State Univ. Press, Ames, IA U.S.A.

Bortolotti, G.R. 1984. Criteria for determining age and sex of nestling Bald Eagles. Journal of Field Ornithology 55:467-481.

Bowerman, W.W., A.S. Roe, M.J. Gilbertson, D.A. Best, J.G. SikARSkie, R.S. Mitchell, AND C.L. Summer. 2002. Using Bald Eagles to indicate the health of the Great Lakes environment. Lakes and Reservoirs Research and Management 7:183-187.
Braselton, W.E., G.L. Meerdink, H.D. Stowe, and S.R. TONSAGER. 1981. Experience with multi-element analysis in diagnostic clinical toxicology and nutrition. American Association of Veterinary Laboratory Diagnosticians, 24th Annual Proceedings: 111-126.

Cohen, M., R. Artz, R. Draxler, P. Miller, L. Poissant, D. Niemi, D. Ratte, M. Deslauriers, R. Duval, R. Laurin, J. Slotnick, T. Nettsheim, And J. McDonald. 2004. Modeling the atmospheric transport and deposition of mercury to the Great Lakes. Environmental Research 95:247-265.

Compton, B.B., R.J. Mackie, AND G.L. Dusek. 1988. Factors influencing the distribution of white-tailed deer in riparian habitats. Journal of Wildlife Management 52:544-548.

Cuvin-ARALAR, L.A. AND R.W. Furness. 1991. Mercury and selenium interaction: a review. Ecotoxicology and Environmental Safety 21:348-364.

DeSorbo, C.R. And D.C. Evers. 2005. Evaluating exposure of Maine's Bald Eagle population to mercury: assessing impacts on productivity and spatial exposure patterns. Report BRI 2005-08, BioDiversity Research Institute, Gorham, ME U.S.A.

Dusek, G.L., R.J. Mackie, J.D. Herriges, JR., And B.B. CompTON. 1989. Population ecology of white-tailed deer along the lower Yellowstone River. Wildlife Monographs 104:3-68.

Dykstra, C.R., W.T. Route, M.W. Meyer, And P.W. RasmusSEN. 2010. Contaminant concentrations in Bald Eagles nesting on Lake Superior, the upper Mississippi River, and the St. Croix River. Journal of Great Lakes Research 36:561-569.

ElliotT, J.E. AND M.L. HARRIS. 2001/2002. An ecotoxicological assessment of chlorinated hydrocarbons effects on Bald Eagle populations. Reviews in Toxicology 4:1-60.

Evers, D.C., N.M. Burgess, L. Champoux, B. Hoskins, A. Major, W.M. Goodale, R.J. Taylor, R. Poppenga, and T. DAIGLE. 2005. Patterns and interpretation of mercury exposure in freshwater avian communities in northeastern North America. Ecotoxicology 14:193-221.

, O.P. Lane, L. Savoy, and W.M. Goodale. 2004. Assessing the impacts of methylmercury on piscivorous wildlife using a wildlife criterion value based on the Common Loon, 1998-2003. Report BRI 2004-05, BioDiversity Research Institute, Gorham, ME U.S.A.

Galat, D.L., C.R. Berry, JR., E.J. Peters, and R.G. White. 2005. Missouri River basin. Pages 427-480 in A.C. Benke and C.E. Cushing [EDs.], Rivers of North America. Elsevier Academic Press, Burlington, MA U.S.A.

Greater Yellowstone Bald Eagle Working Group. 1996. Greater Yellowstone Bald Eagle management plan: 1995 update. Greater Yellowstone Bald Eagle Working Group. Wyoming Game and Fish Department, Lander, WY U.S.A.

Hammond, C.A.M. 2010. Montana Bald Eagle status report 2009. Montana Fish, Wildlife, and Parks, Helena, MT U.S.A. 
HaRmata, A.R. 2011. Environmental contaminants in tissues of Bald Eagles sampled in southwestern Montana, 2006-08. Journal of Raptor Research 45:119-135.

- AND B. OAKLEAF. 1992. Bald Eagles of the Greater Yellowstone ecosystem: an ecological study with emphasis on Snake River, Wyoming. Wyoming Game and Fish Department, Lander, WY U.S.A.

- AND M. Restani. 1995. Environmental contaminants and cholinesterase in blood of vernal migrant Bald and Golden eagles in Montana. Intermountain Journal of Sciences 1:1-15.

HeInZ, G.H. 1996. Mercury poisoning in wildlife. Pages 118-127 in A. Fairbrother, L.N. Locke, and G.L. Hoff [EDs.], Noninfectious diseases in wildlife, Second Ed. Iowa State Univ. Press, Ames, IA U.S.A.

Hollamby, S., J. Afema-Azikuru, J.G. Sikarskie, J.B. KaneEne, W.W. Bowerman, S.D. Fitzgerald, K. Cameron, A.R. Gandolf, G.N. Hul, C. Dranzoa, and W.K. Rumbeiha. 2004. Mercury and persistent organic pollutant concentrations in African Fish Eagles, Marabou Storks, and Nile tilapia in Uganda. Journal of Wildlife Diseases 40:501-514.

Hopkins, W.A., L.B. Hopkins, J.M. UnRine, J. SnOdgrass, AND J.D. ElLIOT. 2007. Mercury concentrations in tissues of Osprey from the Carolinas, USA. Journal of Wildlife Management 71:1819-1829.

Jagoe, C.H., A.L. Bryan, JR., H.A. Brant, T.M. Murphy, AND I.L. BRISBIN, JR. 2002. Mercury in Bald Eagle nestlings from South Carolina, USA. Journal of Wildlife Diseases 38:706-712.

Montana Bald Eagle Working Group. 1994. Montana Bald Eagle management plan. July 1994. USDI, Bureau of Reclamation, Montana Projects Office, Billings, MT U.S.A.

NATIONAL ReSEARCH COUNCIL. 1978. An assessment of mercury in the environment. Environmental studies board, panel on mercury of the coordinating committee for scientific and technical assessments of environmental pollutants. Commission on Natural Resources, National Research Council, National Academy of Sciences, Washington, DC U.S.A.

NriAgU, J.O. 1989. A global assessment of natural sources of atmospheric trace metals. Nature 338:47-49.

NuCCIO, V. 2000. Coal-bed methane: potential and concerns. USGS Fact Sheet FS-123-00, Washington, DC U.S.A.

Olsson, A., K. Ceder, Å. Bergman, and B. Helander. 2000. Nestling blood of White-tailed Sea Eagles (Haliaeetus albicilla) as an indicator of territorial exposure to organohalogen compounds-an evaluation. Environmental Science and Technology 34:2733-2740.

REDIG, P.T. 1984. An investigation into the effects of lead poisoning on Bald Eagles and other raptors: final report. Minnesota Endangered Species Program Study 100A-100B, Univ. of Minnesota, St. Paul, MN U.S.A.

Regele, S. And J. Stark. 2000. Coal bed methane gas development in Montana, some biological issues. Montana Department of Environmental Quality, Industrial and Energy Minerals Bureau. http://www.deq.state.mt. us/CoaIBedMethane/lssues.asp\#WaterQ_Q (last accessed 20 March 2009).
Rice, C.A., M.S. Ellis, AND J.H. Bullock, JR. 2000. Water co-produced with coal-bed methane in the Powder River basin, Wyoming: preliminary compositional data. United States Department of the Interior and United States Geological Survey. Open File-Report 00-372, Washington, DC U.S.A.

Rutkiewicz, J., D.-H. Nam, T. Cooley, K. Neumann, I.B. Padilla, W. Route, S. Strom, and N. Basu. 2011. Mercury exposure and neurochemical impacts in Bald Eagles across several Great Lakes states. Ecotoxicology 20:1669-1676.

Scheuhammer, A.M., A.H. Wong, AND D. Bond. 1998. Mercury and selenium accumulation in Common Loons and Common Mergansers from eastern Canada. Environmental Toxicology and Chemistry 17:197-201.

- , N. Basu, N. Burgess, J.E. Elliott, G.D. Campbell, AND M. WAYLAND. 2008. Relationships among mercury, selenium, and neurochemical parameters in Common Loons (Gavia immer) and Bald Eagles (Haliaeetus leucocephalus). Ecotoxicology 17:93-101.

SPSS. 2006. SPSS Base 14.0 for Windows: user's guide. SPSS, Chicago, IL U.S.A.

Stanford, J.A., F.R. Hauer, S.V. Gregory, And E.B. SNyder. 2005. Columbia River basin. Pages 591-653 in A.C. Benke and C.E. Cushing [EDS.], Rivers of North America. Elsevier Academic Press, Burlington, MA U.S.A.

Stearns, M., J.A. Tindal, G. Cronin, M.J. Friedel, and E. BERGQUIST. 2005. Effects of coal-bed methane discharge waters on the vegetation and soil ecosystem in Powder River basin, Wyoming. Water, Air, and Soil Pollution 168:33-57.

Stowe, H.D., W.W. Braselton, J.B. Kaneen, and M. Slanker. 1985. Multielement assays of bovine tissue specimens by inductively coupled argon plasma emission spectroscopy. American Journal of Veterinary Research 46:561-565.

Swenson, J.E., K.L. Alt, AND R.L. EnG. 1986. Ecology of Bald Eagles in the Greater Yellowstone ecosystem. Wildlife Monographs 95:3-46.

United States Department of Energy. 2007. Tracking new coal fired power plants. National Energy Technology Laboratory. http://netl.doe.gov/technologies/coalpower/ refshelf.html (last accessed 19 March 2009).

United States Environmental Protection Agency. 1997. Mercury study report to Congress. EPA-452/R-97-003, United States Environmental Protection Agency, Washington, DC U.S.A.

United States Fish and Wildlife Service. 2006. Draft national Bald Eagle management guidelines, USDI, Washington, DC U.S.A.

WEECH, S.A., L.K. WiLSON, K.M. LANGELIER, AND J.E. ELLIOTT. 2003. Mercury residues in livers of Bald Eagles found dead or dying in British Columbia, Canada (1987-94). Archives of Environmental Contamination and Toxicology 45:562-569.

Wiemeyer, S.N., R.W. Frenzel, R.G. Anthony, B.R. MCClelland, AND R.L. KNight. 1989. Environmental contaminants in blood of western Bald Eagles. Journal of Raptor Research 23:140-146. 
WILbUR, S. 2007. Rapid analysis of high-matrix environmental samples using Agilent 7500cx ICP MS. Agilent Technologies, Inc., Bellevue, WA U.S.A.

Wood, P.B., J.H. White, A. Steffer, J.M. Wood, C.F. FaceMIRE, AND H.F. PERCIVAL. 1996. Mercury concentrations in tissues of Florida Bald Eagles. Journal of Wildlife Management 60:178-185.
Zelt, R.B., G.K. Boughton, K.A. Miller, J.P. Mason, AND L.M. GianaKos. 1999. Environmental setting of the Yellowstone River basin, Montana, North Dakota, and Wyoming. United States Geological Survey Water-Resources Investigations Report 98-4269, Washington, DC U.S.A.

Received 2 September 2011; accepted 20 March 2012 